\title{
B Chromosomes in Grasshoppers: Different Origins and Pathways to the Modern $B_{s}$
}

\author{
Ilyas Yerkinovich Jetybayev $1,2, * \mathbb{C}$, Alexander Gennadievich Bugrov 2,3, \\ Victoria Vladimirovna Dzyubenko ${ }^{3}$ and Nikolay Borisovich Rubtsov ${ }^{1,3}$ \\ 1 The Federal Research Center Institute of Cytology and Genetics, Russian Academy of Sciences, \\ Siberian Branch, Lavrentjev Ave., 10, 630090 Novosibirsk, Russia; rubt@bionet.nsc.ru \\ 2 Institute of Systematics and Ecology of Animals, Russian Academy of Sciences, Siberian Branch, \\ Frunze str. 11, 630091 Novosibirsk, Russia; bugrov@fen.nsu.ru \\ 3 Novosibirsk State University, Pirogov str., 2, 630090 Novosibirsk, Russia; victoriad@mail.ru \\ * Correspondence: jetybayev@mail.ru; Tel.: +7-383-363-49-63 (ext. 1027)
}

Received: 28 August 2018; Accepted: 11 October 2018; Published: 18 October 2018

\begin{abstract}
B}$ chromosomes $\left(\mathrm{B}_{\mathrm{s}}\right)$ were described in most taxa of eukaryotes and in around $11.9 \%$ of studied Orthopteran species. In some grasshopper species, their evolution has led to many $\mathrm{B}$ chromosome morphotypes. We studied the $\mathrm{B}_{\mathrm{s}}$ in nine species (Nocaracris tardus, Nocaracris cyanipes, Aeropus sibiricus, Chorthippus jacobsoni, Chorthippus apricarius, Bryodema gebleri, Asiotmethis heptapotamicus songoricus, Podisma sapporensis, and Eyprepocnemis plorans), analyzing their possible origin and further development. The studied $\mathrm{B}_{\mathrm{S}}$ consisted of $\mathrm{C}$-positive or $\mathrm{C}$-positive and $\mathrm{C}$-negative regions. Analyzing new data and considering current hypotheses, we suggest that $B_{s}$ in grasshoppers could arise through different mechanisms and from different chromosomes of the main set. We gave our special attention to the $B_{s}$ with $C$-negative regions and suggest a new hypothesis of $B$ chromosome formation from large or medium autosomes. This hypothesis includes dissemination of repetitive sequences and development of intercalary heterochromatic blocks in euchromatic chromosome arm followed by deletion of euchromatic regions located between them. The hypothesis is based on the findings of the Eyprepocnemis plorans specimens with autosome containing numerous intercalary repeat clusters, analysis of C-positive $B_{\mathrm{s}}$ in Eyprepocnemis plorans and Podisma sapporensis containing intercalary and terminal C-negative regions, and development of heterochromatic neo-Y chromosome in some Pamphagidae grasshoppers.
\end{abstract}

Keywords: B chromosomes; grasshoppers; DNA composition; repeat clusters; euchromatin degradation; microdissected DNA probes

\section{Introduction}

The $\mathrm{B}$ chromosomes $\left(\mathrm{B}_{\mathrm{s}}\right)$ were initially described in 1907 as additional elements to the standard karyotype in species of the Metapodius genus (Hemiptera) [1]. The number of eukaryotic species with $\mathrm{B}_{\mathrm{S}}$ were estimated from 1685 [2] in 1980 to more than 2828 [3] in 2017. Among Orthopteran species, $B_{s}$ were described in 191 species, which constitutes $11,9 \%$ of studied species [4]. Often $B_{s}$ are enriched with repetitive sequences and are highly heterochromatic. The presence of $B_{S}$ is non-essential for organism development and provides little or no effect [5-8].

Despite intensive studies and wide range of used methods, the origin and further evolution of $B_{s}$ remains an intriguing question. None of the approaches can provide compelling evidence on this topic. Modern views on these questions are still full of hypotheses and assumptions. However, all researchers agree, that the $\mathrm{B}_{\mathrm{s}}$ can arise either from rearranged chromosomes of a basic set or from material resulted from interspecific hybridization [5]. 
In the former case, the $B_{s}$ often derive from pericentric regions of $A$ chromosomes $\left(A_{s}\right)$ which resulted from deletion of the whole or almost of the whole euchromatic part of a chromosome. The $B_{s}$ originated from this event are small and mostly C-positive. However, there are many other morphotypes of $B_{s}$ in grasshoppers, where the mechanism of their origination and further evolution is not so clear.

Frequently the $\mathrm{X}$ chromosome and smallest autosomes are suggested as the possible ancestors of the $B_{s}$ in grasshoppers: the $X$ shows special meiotic behavior and dosage compensation mechanisms that can reduce problems caused by partial aneuploidy $[5,6,9,10]$. Small autosomes traditionally were also considered as a possible ancestor of the $B_{\mathrm{s}}$ because they contain fewer genes and thus additional small autosome could be better tolerated than other large $A_{s}[9]$. Recently it was shown that some small autosomes usually contain many repetitive DNA [11-13] strands and often they contain large additional C-positive blocks on their distal part [14,15].

Because of heteropicnosity and univalency of many $B_{s}$, they resemble the $X$ in meiosis. This similarity is a circumstantial evidence in favor of the $X$ chromosome origin of $B_{s}$ but it cannot be acknowledged to be the direct proof [10]. Molecular markers also do not provide compelling evidence of the $B$ chromosome origin. For instance, mutual location of 180 bp satellite DNA (satDNA) and ribosomal DNA (rDNA) cluster on the $\mathrm{B}_{\mathrm{s}}$ and on the $\mathrm{X}$ in Eyprepocnemis plorans supported the hypothesis that the $\mathrm{X}$ was the ancestor of these $B_{S}[16,17]$. However, sequencing of internal transcribed spacer (ITS) of 45S rRNA gene revealed unique variants of the ITS present in each chromosome. The ITS from the autosome S11 appeared to be the closest one to the ITS from the $B$ chromosome [18]. We should also note that sequencing of $B_{s}$ in six mammalian species showed that $B_{s}$ can contain DNA fragments from different $A_{s}[19-21]$, which significantly puzzles the question of the $B_{s}$ origin.

The large autosomes are rarely considered as possible ancestors of the $B_{s}$ [22]. Furthermore, most of the $B$ chromosome studies are focused on $C$-positive $B_{s}$ and rarely discuss the origin $C$-negative $B$ chromosome regions. Here, we described $B_{s}$ in 9 grasshopper species, examined their various origins including the large or medium autosomes, and proposed that they also might be considered as an ancestor of such $C$-negative $B_{s}$.

\section{Material and Methods}

Specimens of nine grasshopper species were collected during field season of 1987 and 2000-2017 in different locations indicated in the Table 1.

Table 1. Studied species and locations of their collection.

\begin{tabular}{|c|c|c|c|c|}
\hline Taxa & Species Name & Location & Year & $N$ \\
\hline \multicolumn{5}{|l|}{ Acrididae } \\
\hline \multirow[t]{3}{*}{ Gomphocerinae } & Chorthippus apricarius (L.) & $\begin{array}{l}\text { Foothills of Trans-Ili Alatau } \\
\text { mountains near Almaty, } \\
\text { Kazakhstan }\end{array}$ & 2005 & $3 \odot$ from 29 \\
\hline & Chorthippus jacobsoni (Ikonn.) & $\begin{array}{l}\text { Foothills of Trans-Ili Alatau } \\
\text { mountains near Almaty, } \\
\text { Kazakhstan }\end{array}$ & 2007 & $7 \odot$ from 39 \\
\hline & Aeropus sibiricus (L.) & $\begin{array}{l}\text { Kurai steppe, Altay mountains, } \\
\text { Russian Federation }\end{array}$ & 2007 & $60^{x}$ \\
\hline Oedipodinae & Bryodema gebleri (F-W.) & $\begin{array}{l}\text { Kurai steppe, Altay mountains, } \\
\text { Russian Federation }\end{array}$ & 2017 & $12 \sigma^{7}$ \\
\hline Melanoplinae & $\begin{array}{l}\text { Podisma sapporensis } \\
\text { sapporensis Shir. }\end{array}$ & Hokkaido, Japan & $\begin{array}{l}2000 \\
2005\end{array}$ & $157 \sigma^{7}, 37 \odot$ \\
\hline
\end{tabular}


Table 1. Cont.

\begin{tabular}{|c|c|c|c|c|}
\hline Taxa & Species Name & Location & Year & $N$ \\
\hline \multirow[t]{2}{*}{ Eyprepocnemidinae } & $\begin{array}{l}\text { Eyprepocnemis plorans plorans } \\
\text { (Charp.) }\end{array}$ & $\begin{array}{c}\text { Megri and Yerevan, Armenia, } \\
\text { Antalia, Turkey, } \\
\text { Malaga, Spain (kindly provided } \\
\text { by JPM Camacho) }\end{array}$ & $\begin{array}{l}2003 \\
2007\end{array}$ & $\begin{array}{l}3810^{7} \\
5510^{x}\end{array}$ \\
\hline & $\begin{array}{l}\text { Eyprepocnemis plorans } \\
\text { meridionalis Uv. }\end{array}$ & Springbok, South Africa & 2004 & $330^{\pi}$ \\
\hline \multicolumn{5}{|l|}{ Pamphagidae } \\
\hline \multirow[t]{2}{*}{ Pamphaginae } & $\begin{array}{l}\text { Nocaracris tardus Ünal, } \\
\text { Bugrov \& Jetybayev }\end{array}$ & Sultandag mountains, Turkey & 2014 & $7 \sigma^{7}$ \\
\hline & Nocaracris cyanipes (F-W.) & $\begin{array}{l}\text { Prielbrusie National park } \\
\text { Kabardino-Balkaria, Russia }\end{array}$ & 1987 & $50^{\pi}$ \\
\hline Trinchinae & $\begin{array}{c}\text { Asiotmethis heptapotamicus } \\
\text { songoricus Shum. }\end{array}$ & Ayagoz, East Kazakhstan & 2015 & $180^{7}$ \\
\hline
\end{tabular}

$\mathrm{N}$-Number of studied samples; $\odot$-eggpods.

\subsection{Chromosome Preparation}

Testes of males were fixed in the field according to standard methods [23]. Females were kept alive and reared in our laboratory to obtain eggpods. The meiotic chromosomes and metaphase chromosomes of somatic cells were prepared from male testes and embryos according to standard procedures [24].

\subsection{DNA Probes Generation}

Chromosome microdissection was performed according to standard procedure as described earlier [24]. Microdissected DNA libraries (Table 2) were generated according to standard protocol from 8-28 copies of the chromosome or chromosome region collected by extended glass needle using a micromanipulator MR (Zeiss, Oberkochen, Germany). The WCPNtaB (Whole Chromosome Paint of Nocaracris tardus B) DNA probe was generated from 20 copies of $B_{S}$ of the Nocaracris tardus specimen with the $4 \mathrm{~B}_{\mathrm{s}}$ per cell. The PCPCapBq (Partial Chromosome Paint of Chorthippus apricarius B q arm) DNA probe was generated from the 8 copies of long arm of the $\mathrm{B}$ chromosome and PCPCapAc (Partial Chromosome Paint of Chorthippus apricarius A centromeric region)) DNA probe was generated from 8 copies of pericentromeric C-positive region of one of autosome of Chorthippus apricarius. A microdissected WCPEplBa4 (Whole Chromosome Paint of Eyprepocnemis plorans Ba4) DNA probe was generated from eight copies of the Ba4 of Eyprepocnemis plorans. The amplification of DNA isolated from the microdissected material was carried out using polymerase chain reaction (PCR) with partly degenerated primer MW6 (DOP-PCR) [25] as described earlier [26]. The PCPPsaB1-B2dist (Partial Chromosome Paint of Podisma sapporensis distal parts of B1 and B2) DNA probe was generated from 28 copies of distal C-negative regions of the B1 and B2 chromosomes of Podisma sappoernsis. Dissection was performed from central part of B1-B2 bivalent that formed chiasma in the distal parts of the $\mathrm{B}_{\mathrm{s}}$. Dissected material was amplified using a GenomePlex Single Cell Whole Genome Amplification Kit (WGA4) (Sigma-Aldrich, St. Louis, MO, USA) according to the manufacturer's protocol. DNA labelling was carried out in additional 15 cycles of PCR in presence of Flu- or TAMRA-dUTP (Genetyx, Novosibirsk, Russia) in additional 20 PCR cycles using WGA3 kit (Sigma-Aldrich, St. Louis, MO, USA) or with 20 high temperature cycles of DOP-PCR. DNA probe for rDNA and telomeric repeats was prepared as previously described [27]. 
Table 2. Microdissected DNA probes.

\begin{tabular}{ccc}
\hline DNA probe & Species & Dissected Chromosome/Region \\
\hline WCPNtaB & Nocaracris tardus & Whole B \\
PCPCapBq & Chorthippus apricarius & Long arm of the B \\
PCPCapAc & Chorthippus apricarius & Pericentric region of autosome \\
WCPEplBa4 & Eyprepocnemis plorans & Whole Ba4 \\
PCPPsaB1-B2dist & Podisma sapporensis & Distal parts of B1 and B2 \\
\hline
\end{tabular}

\subsection{C-Banding and Fluorescence In Situ Hybridization (FISH) Technique}

C-banding and fluorescence in situ hybridization (FISH) were performed as described earlier $[28,29]$.

\subsection{Microscopy}

Microscopy was performed at the Centre for Microscopy of Biological Objects (Institute of Cytology and Genetics SB RAS, Novosibirsk, Russia) with an AxioImager.M1 (Zeiss) fluorescence microscope equipped with \#49, \#46HE, \#43HE filter sets (Zeiss), ProgRes MF CCD camera (JenaOptik, Jena, Germany), using Software package ISIS5 (MetaSystems GmbH, Altlussheim, Germany).

\section{Results}

\section{B Chromosome Morphology in Studied Grasshopper Species}

We analyzed $\mathrm{B}_{\mathrm{s}}$ in nine species of grasshoppers: Nocaracris tardus, Nocaracris cyanipes, Aeropus sibiricus, Chorthippus jacobsoni, Chorthippus apricarius, Bryodema gebleri, Asiotmethis heptapotamicus songoricus, Podisma sapporensis, and Eyprepocnemis plorans.

In Nocaracris tardus $\left(2 \mathrm{n}=18+\right.$ neo- $\left.\mathrm{XX}_{+} / \mathrm{neo}^{\mathrm{X}} \mathrm{XY}^{7}\right) \mathrm{B}_{\mathrm{s}}$ were found in 6 out of 7 karyotyped specimens. Number of the $B_{s}$ varied in different specimens from 0 to 4 per cell. All revealed $B_{s}$ were C-positive and very small. Their size was approximately equal to $C$-positive blocks detected in the most of autosomes (Figure 1a). On early stages of meiosis, these $B_{s}$ conjugated with the terminal region of the short arm of the neo-X chromosome (Figure 1b). Two-color FISH with labelled rDNA and telomeric DNA probe showed only telomeric repeats on the B chromosome termini (Figure 1b). FISH with WCPNtaB revealed strong hybridization signal only on the $\mathrm{B}_{\mathrm{s}}$. We observed weaker hybridization signal in centromeric regions of L1 and S8 autosomes (Figure 1c).
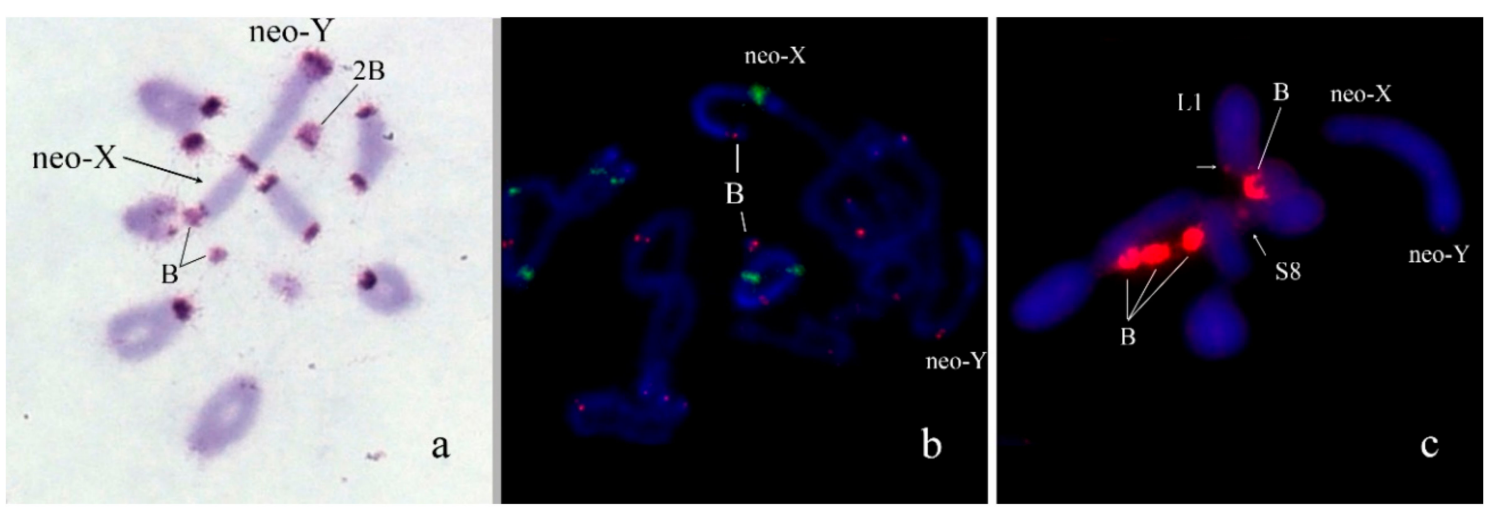

Figure 1. $\mathrm{B}_{\mathrm{s}}$ in meiotic cells of Nocaracris tardus: (a) C-banding; (b) fluorescence in situ hybridization (FISH) with ribosomal DNA (rDNA) (green) and telomeric DNA (red) probes; (c) FISH with WCPPtaB (red) DNA probe. Arrows indicate localization of hybridization signals in pericentric regions of L1 and S8 autosomes. Chromosomes counterstained with 4',6-Diamidino-2-Phenylindole, Dihydrochloride (DAPI) (blue).

In Nocaracris cyanipes $\left(2 n=18+\right.$ neo- $X X+/$ neo- $\left.X Y{ }^{7}\right)$, the only $B$ chromosome was found in the male from Elbrus region of Russia. It was the same as the $\mathrm{B}_{\mathrm{s}}$ of $N$. tardus in size and C-banding pattern. 
Two-color FISH with labelled rDNA and telomeric DNA probe also showed only telomeric repeats clusters on the B chromosome termini. In meiosis, this B chromosome was often located close to a terminal region of the short arm of the neo- $X$ chromosome.

In Aeropus sibiricus $\left(2 \mathrm{n}=16+\mathrm{XX} / \mathrm{X} 0 \sigma^{\top}\right)$, four $\mathrm{B}_{\mathrm{s}}$ were found in one male out of six analyzed specimens. All four $B_{s}$ were present in all studied cells. All of them were medium-sized acrocentrics with pericentromeric C-positive region similar in size to pericentromeric C-positive regions of $A_{s}$. They contain also large C-negative regions. In meiosis, they can be univalents or formed bi-, tri-, and tetravalent (Figure 2a). Two-color FISH with labelled rDNA and telomeric DNA probe revealed on the $B_{s}$ rDNA in C-positive pericentric region and telomeric repeat clusters on the termini of $B_{S}$ (Figure 2b). We observed the same distribution of these repeats in all chromosomes of the set.
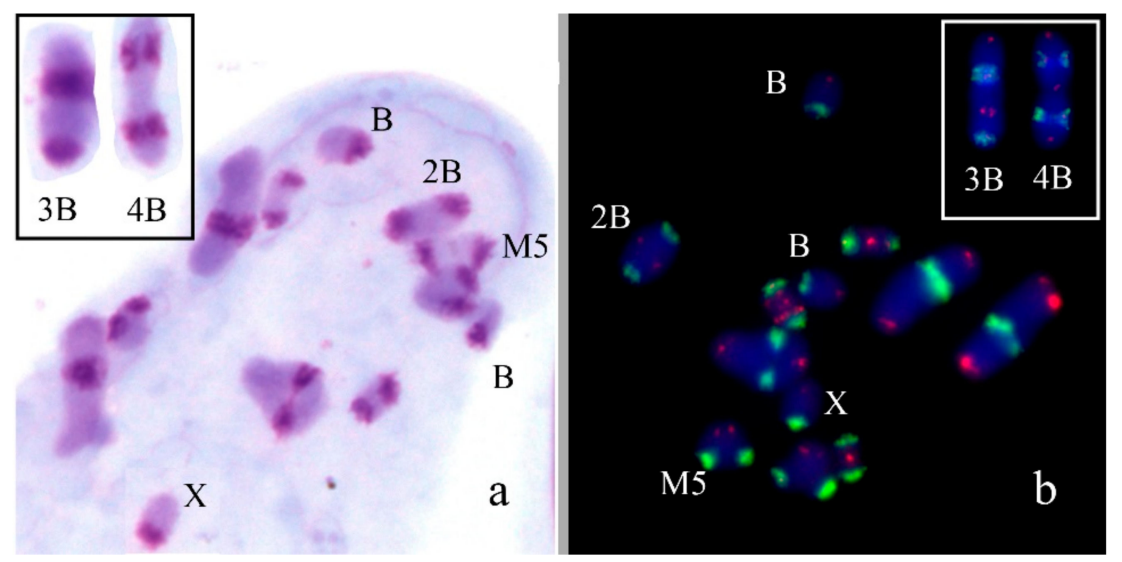

Figure 2. $\mathrm{B}_{\mathrm{s}}$ in meiotic cells of Aeropus sibiricus: (a) C-banding, inset shows trivalent and tetravalent of $\mathrm{B}_{\mathrm{s}}$; (b) FISH with rDNA (green) and telomeric DNA (red) probes, chromosomes counterstained with DAPI (blue), inset shows trivalent and tetravalent of $B_{s}$.

In Chorthippus jacobsoni $\left(2 \mathrm{n}=16+\mathrm{XX}+\mathrm{X} 0 \mathrm{o}^{7}\right)$, the $\mathrm{B}_{\mathrm{s}}$ were found in 15 out of 108 analyzed embryos, with one $B$ chromosome per cell. They were metacentrics equal to the $X$ in size with arms similar to arms of M6 autosome. They have large pericentromeric C-positive block and C-negative arms (Figure 3a). They looked like typical isochromosomes. Two-color FISH with rDNA and telomeric DNA probes showed telomeric clusters on the ends of the $\mathrm{B}_{\mathrm{s}}$, the interstitial site of rDNA in two large metacentrics (Figure $3 b$ ). We did not observe any interstitial telomeric signals in pericentric C-positive block of B chromosome, in contrast to pericentric C-positive regions of large autosomes that contained the large cluster of these repeats.

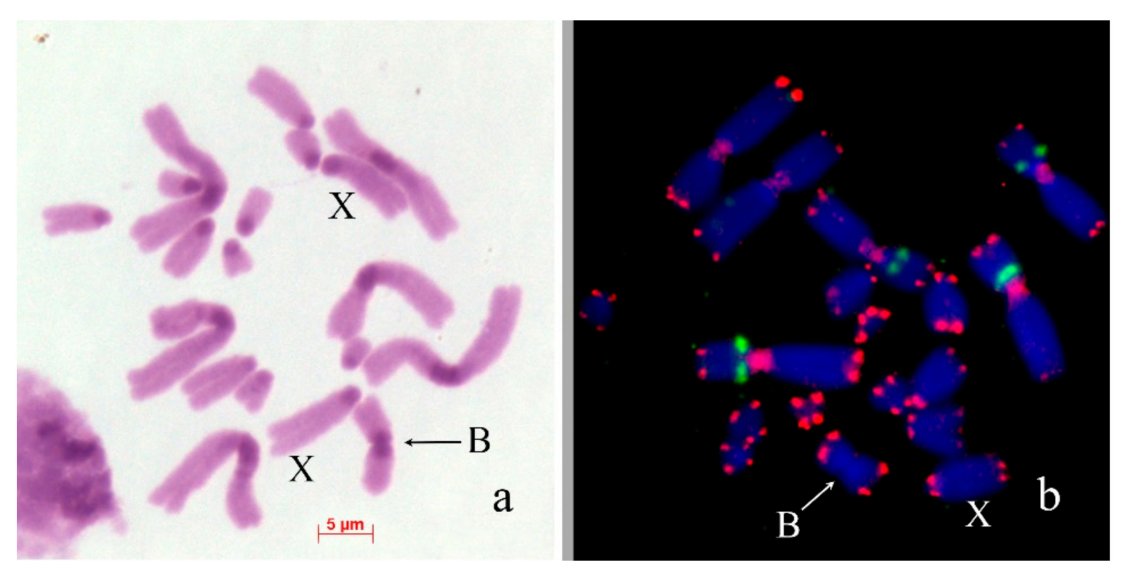

Figure 3. $\mathrm{B}_{\mathrm{s}}$ in mitotic cells of Chorthippus jacobsoni: (a) C-banding; (b) FISH with rDNA (green) and telomeric DNA (red) probes, chromosomes counterstained with DAPI (blue). Arrows indicate $\mathrm{B}_{\mathrm{s}}$. 
In Chorthippus apricarius $\left(2 \mathrm{n}=16+\mathrm{XX} / \mathrm{X} 0 \sigma^{7}\right), \mathrm{B}_{\mathrm{s}}$ were found in seven out of 52 analyzed embryos, with one $\mathrm{B}$ chromosome per cell. The $\mathrm{B}_{\mathrm{s}}$ were submetacentrics equal to the $\mathrm{X}$ in size. $\mathrm{C}$-banding revealed medium-sized pericentric $C$-positive block and large interstitial $C$-positive block in the long arm of the $\mathrm{B}_{\mathrm{s}}$ (Figure 4a). FISH with labeled rDNA did not reveal clusters of rDNA in the $\mathrm{B}_{\mathrm{s}}$ (Figure $4 b$ ). PCPCapBq intensively painted interstitial C-band in the B chromosome arm and distal parts of pericentric regions of most of $A_{s}$. PCPCapAc painted all pericentric C-blocks (Figure 4c). In biarmed L1-L3 chromosomes, hybridization signals were significantly weaker and were observed only in distal part of the pericentric C-bands in their short arms. In L3 autosome, hybridization signals were weaker than in the L1 and L2 autosomes (Figure 4c).
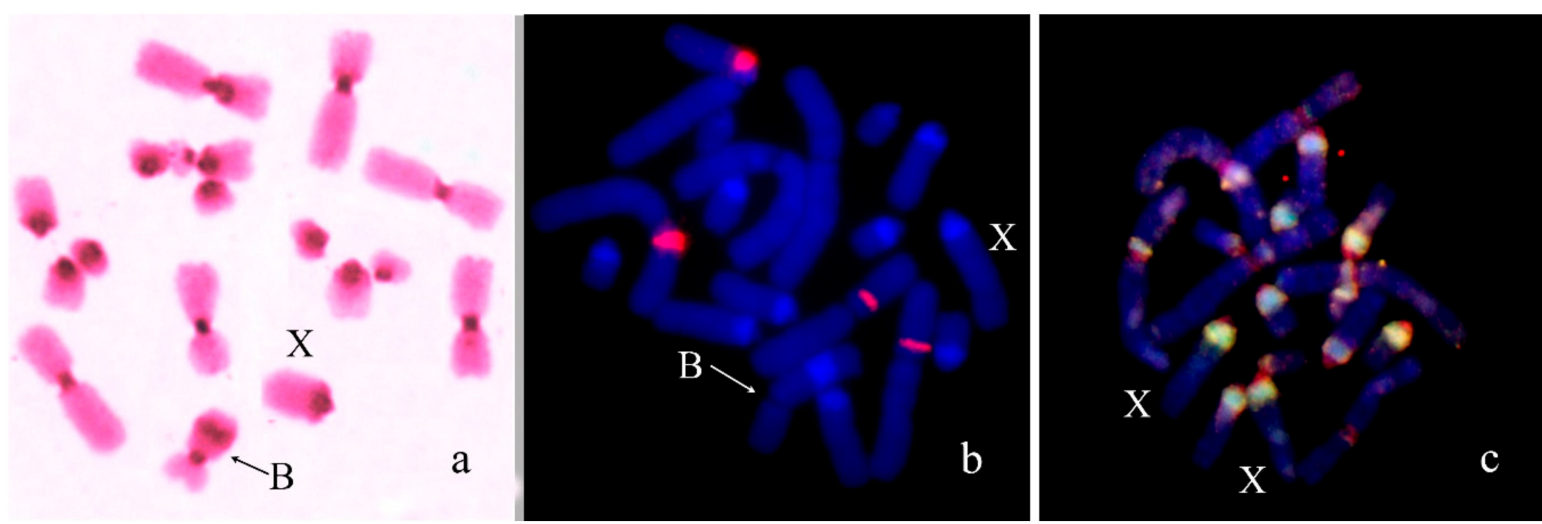

Figure 4. $\mathrm{B}_{\mathrm{S}}$ in mitotic cells of Chorthippus apricarius: (a) C-banding; (b) FISH with rDNA (red) probe; (c) FISH of PCPCapBq (green) and PCPCapAc (red) with main chromosome set. Chromosomes counterstained with DAPI (blue). Arrows indicate $B_{s}$.

In Bryodema gebleri $\left(2 \mathrm{n}=22+\mathrm{XX} / \mathrm{X} 0 \circ^{\top}\right)$, the only $\mathrm{B}$ was found in one out of 12 males from Kurai steppe in Altay region of Russia. It was large acrocentric chromosome with very small C-negative short arm, equal to L3 in size. The B chromosome contained small pericentromeric and six intercalary C-positive blocks in the long arm. Terminal large C-positive block was approximately $1 / 3$ rd of the B chromosome size (Figure 5a). Two-color FISH with labelled rDNA and telomeric DNA probe showed small telomeric repeat cluster on the end of long arm and a large cluster of telomeric repeats in short arm of the B. (Figure 5b).

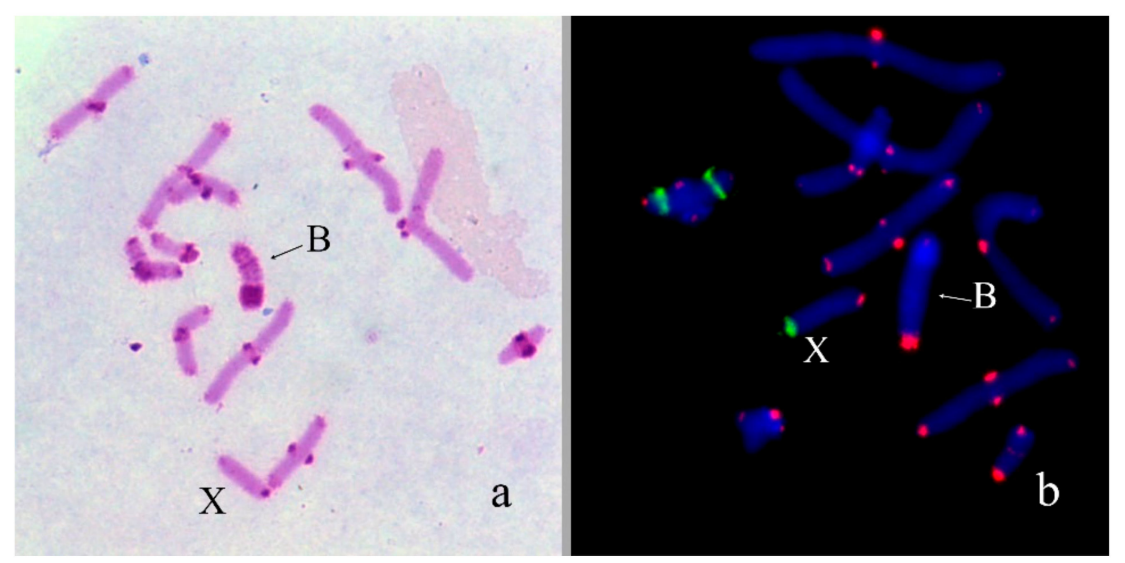

Figure 5. $\mathrm{B}_{\mathrm{s}}$ in meiotic cells of Bryodema gebleri: (a) C-banding; (b) FISH with rDNA (green) and telomeric DNA (red) probes, chromosomes counterstained with DAPI (blue). Arrows indicate $\mathrm{B}_{\mathrm{s}}$.

In Asiotmethis heptapotamicus songoricus $\left(2 \mathrm{n}=18+\right.$ neo-XXo/neo-XY $\left.\mathrm{X} \mathrm{o}^{7}\right)$, the $\mathrm{B}_{\mathrm{s}}$ were found in three out of 20 males from a population near the Ayaguz river, eastern Kazakhstan. In one specimen, two $\mathrm{B}$ chromosomes per cell were observed. The $\mathrm{B}_{\mathrm{s}}$ were approximately equal to M6-S7 autosomes in 
size. They were partly $C$-negative and a proximal half of the $B_{s}$ contained two interstitial C-positive blocks in addition to pericentromeric $C$-positive region. In meiosis of one specimen, two $B_{s}$ formed bivalents (Figure 6a). Two-color FISH with labelled rDNA and a telomeric DNA probe showed only telomeric repeat clusters on the termini of the $\mathrm{B}_{\mathrm{s}}$ (Figure $6 \mathrm{~b}$ ).

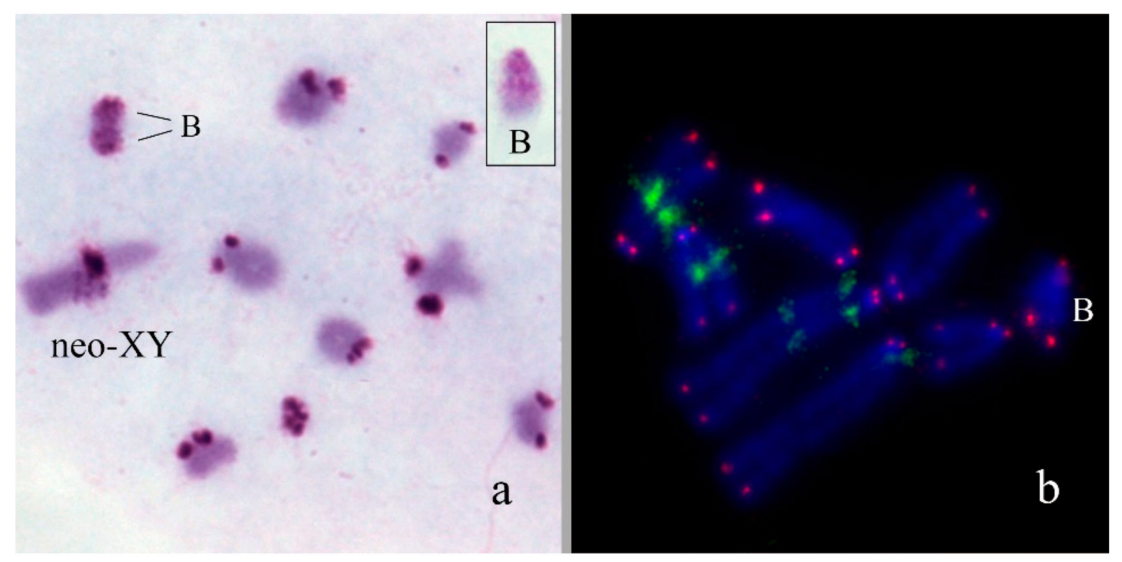

Figure 6. $\mathrm{B}_{\mathrm{S}}$ in meiotic and mitotic cells of Asiotmethis heptapotamicus songoricus: (a) C-banding, inset shows mitotic B chromosome; (b) FISH with rDNA (green) and telomeric DNA (red) probes, chromosomes counterstained with DAPI (blue).

We previously analyzed the populations of Podisma sapporensis $\left(2 \mathrm{n}=22+\mathrm{XX}+\mathrm{X} 00^{7}\right.$ and

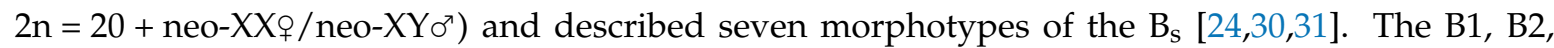
$\mathrm{B} 3, \mathrm{~B} 4$ and B6iso morphotypes correspond to heavily heterochromatic $\mathrm{B}_{\mathrm{s}}$ with $\mathrm{C}$-negative region(s) in the distal part of the chromosomes. In B1 and B2 morphotypes, interstitial C-negative regions were interlaced with C-positive ones. In the B3 morphotypes C-negative regions were small. The B6iso morphotype was characterized with terminal C-negative regions in both chromosome arms. The B5iso exhibited multiple small C-positive regions dispersed along the whole chromosome. Finally, the B7 chromosome was almost fully C-negative (Figure 7). In meiosis, the B1 and B2 conjugated with their distal C-negative regions (Figure 8c).

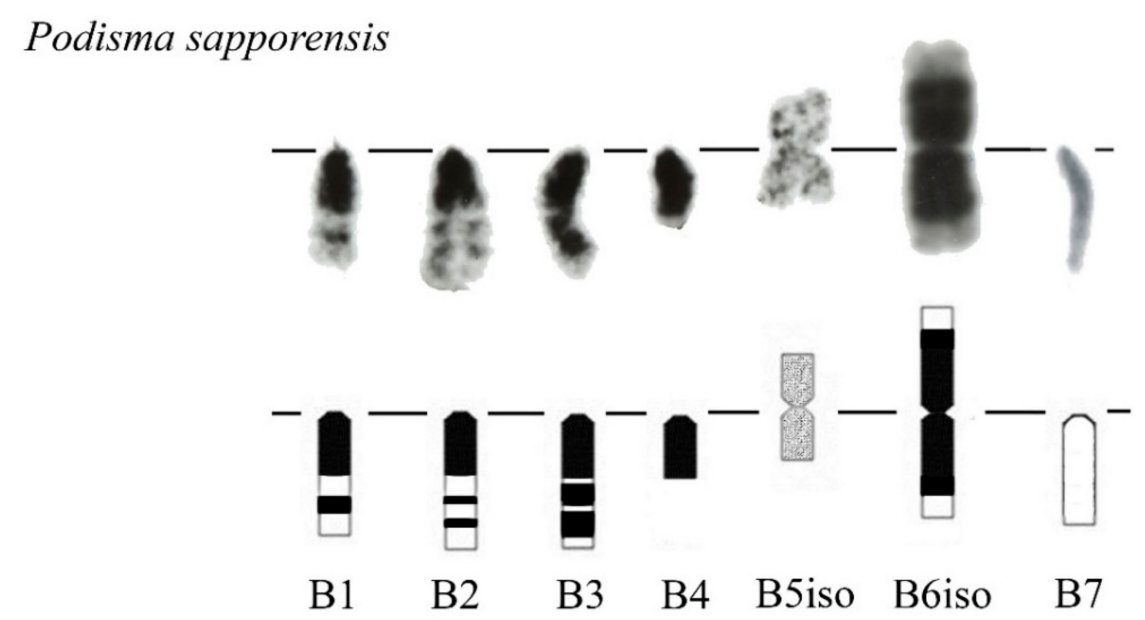

Figure 7. Morphotypes of B chromosome in Podisma sapporensis according to [30].

Fluorescence in situ hybridization (FISH) with rDNA and telomeric DNA probes showed that C-positive regions of B1 and B2 morphotypes were enriched with rDNA. We observed telomeric repeats on the ends of all chromosomes. In addition to these clusters, an interstitial telomeric cluster was revealed, on the border of their distal interstitial C-positive block and interstitial C-negative region in the B1 (Figure 8a,b). The PCPPsaB1-B2dist DNA probe was probably contaminated with 
material of C-positive regions. Consequently, FISH with PCPPsaB1-B2dist gave a very strong signal on $\mathrm{C}$-positive regions of the $\mathrm{B}_{\mathrm{s}}$, masking the signal in original $\mathrm{C}$-negative region (Figure 8c). Patterns of FISH signal with this microdissected DNA probe and labeled rDNA on the $\mathrm{B}_{\mathrm{s}}$ were very similar, suggesting that FISH with this microdissected DNA probe showed mainly the regions highly enriched with rDNA (Figure 8b).
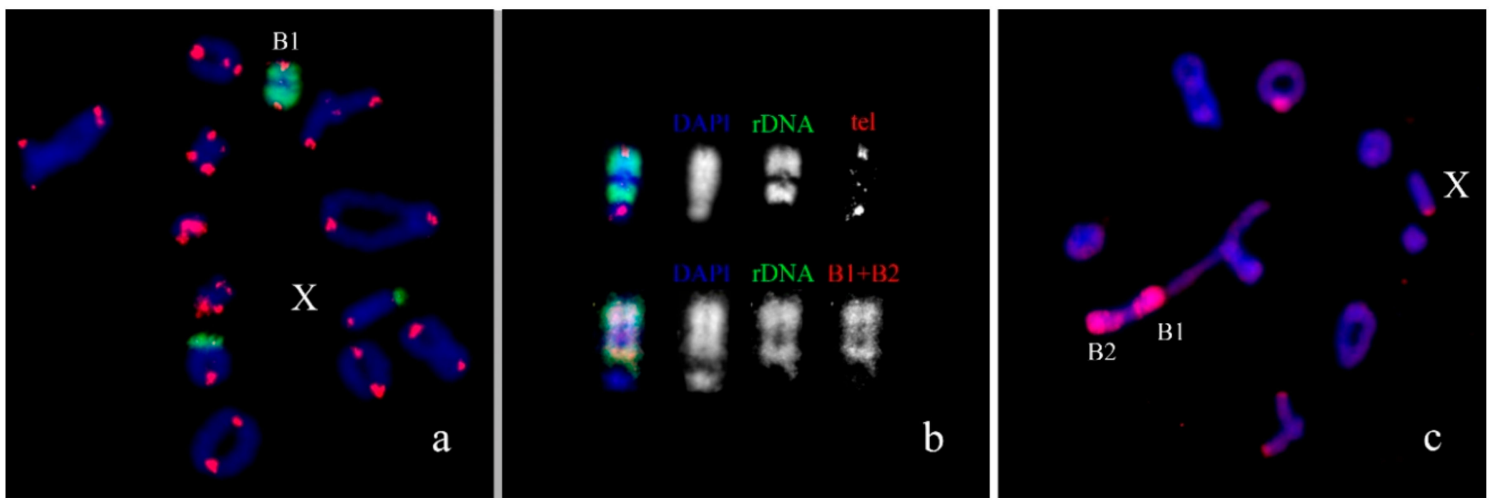

Figure 8. Fluorescence in situ hybridization (FISH) of DNA probes with meiotic cells of Podisma sapporensis:

(a) rDNA (green) and telomeric DNA (red) probes; (b) localization of DNA probes on B1 chromosome;

(c) PCPPsaB1-B2dist (red). Chromosomes counterstained with DAPI (blue).

In Eyprepocnemis plorans $\left(2 \mathrm{n}=22+\mathrm{XX} / \mathrm{X} 0 \sigma^{\top}\right)$, five morphotypes of the $\mathrm{B}_{\mathrm{s}}$ were revealed in eastern populations from Armenia and Turkey (Figure 9) [32]. The Ba1 and Ba2 were large acrocentrics, equal or larger to the $\mathrm{X}$ and mostly $\mathrm{C}$-positive. Small C-negative arm was revealed in Ba2 chromosome. The Ba3 chromosome was fully $\mathrm{C}$-negative, as well as Ba3iso. The Ba4 was equal in size to the smallest autosome and was mostly C-negative with small pericentric C-positive region [32]. The Ba5 was medium-sized with multiple interstitial C-positive blocks along the whole chromosome (Figure 9). Two additional morphotypes of the $B_{S}$ were found in populations from Turkey [32]. The Bt chromosome was small C-positive acrocentric. The Btmini chromosome was smaller than Bt and C-negative (Figure 9). In addition to eastern morphotypes of $B_{s}$, we studied B24 morphotype from Spain. It is a C-positive medium sized B chromosome with interstitial and distal C-negative regions. Regions of these $\mathrm{B}_{\mathrm{s}}$ painted with labeled $\mathrm{rDNA}$ and WCPEplBa4 DNA probe are shown in Figures 9 and 10.

\section{Eyprepocnemis plorans}

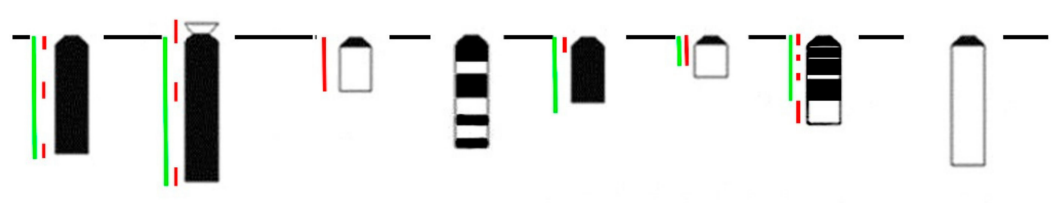

Ba1 Ba2 Ba4 Ba5 Bt Btmini B24 X

Figure 9. Schematic image of C-banding patterns and localization of rDNA (green line) and WCPEplBa4 DNA probes (red line) of different morphotypes of $\mathrm{B}_{\mathrm{s}}$ in Eyprepocnemis plorans. The $\mathrm{X}$ is shown for size comparison.

Fluorescence in situ hybridization with WCPEplBa4 also intensively painted the whole S10 autosome on metaphase plates of specimens from Armenian (Figure 10a,c,d), Spanish (Figure 10b), Turkish (Figure 10e,f) and South African (Figure 10g) populations. In the Spanish population the S10 carried a large C-positive pericentric region that was not painted with the WCPEplBa4 while its C-negative part was strongly painted with the WCPEplBa4 (Figure 10b). 
FISH with WCPEplBa4 also gave a dot-like signal in centromeric regions of all other A chromosomes of Armenian (Figure 10c) specimens. C-negative material of other chromosomes exhibited a weaker hybridization signal after FISH with WCPEplBa4.

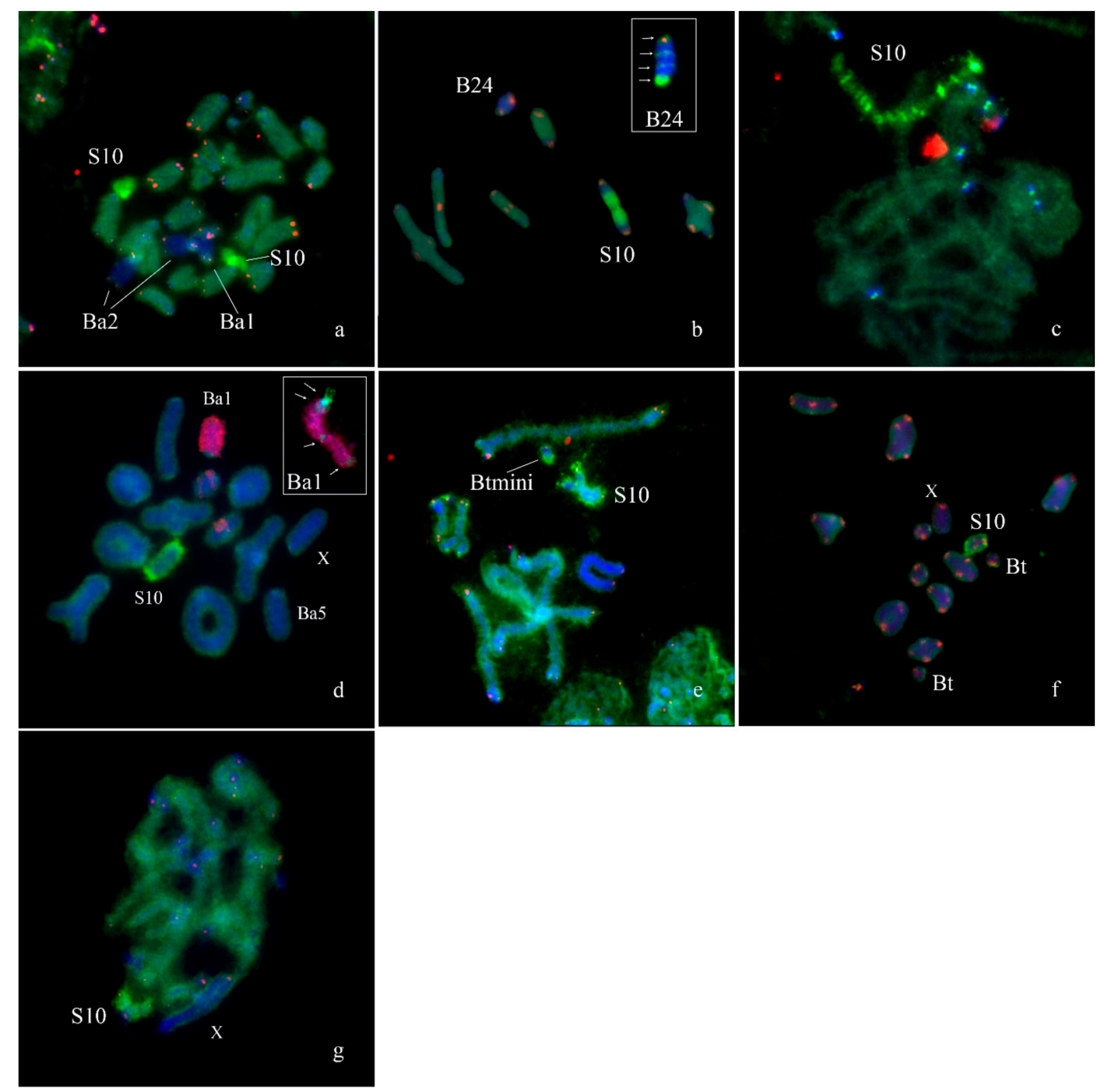

Figure 10. Fluorescence in situ hybridization of DNA probes with chromosomes of Eyprepocnemis plorans: (a) WCPEplBa4 (green) and telomeric DNA probe (red) with individual from Armenian population containing Ba1 and Ba2; (b) WCPEplBa4 (green) and telomeric DNA probe (red) with individual from Spanish population containing B24 (inset shows mitotic B24, arrows indicate signals from WCPEplBa4); (c) WCPEplBa4 (green) and rDNA probe (red) with pachytene chromosomes of individual from Armenian population; (d) WCPEplBa4 (green) and rDNA probe (red) with individual from Armenian population containing $\mathrm{Ba} 1$ and $\mathrm{Ba} 5$, inset shows mitotic $\mathrm{Ba} 1$, arrows indicate signals from WCPEplBa4; (e) WCPEplBa4 (green) and telomeric DNA probe (red) with individual from Turkish population containing Btmini; (f) WCPEplBa4 (green) and telomeric DNA probe (red) with individual from Turkish population containing BT chromosome; (g) WCPEplBa4 (green) and telomeric DNA probe (red) with individual of Eyprepocnemis plorans meridionalis from South Africa.

We revealed unexpected painting pattern after FISH with the WCPEplBa4 and labeled rDNA on the Ba1. FISH with WCPEplBa4 gave a signal on the pericentromeric region, a weaker signal on the distal region of the long arm and a dot-like signal in the proximal region and in the middle of the long arm. At the same time, labeled rDNA painted the whole Ba1 but a proximal part of the pericentromeric region (Figure 10d). On the extended meiotic chromosomes, a hybridization signal of the WCPEplBa4 
on S10 autosome was split into multiple intensive signals interlaced with weaker labeled regions (Figure 10c). The same FISH pattern was observed on the S10 of all studied individuals from Armenian, Turkish, Spanish and South African populations. A FISH pattern of the Ba2 obtained with WCPEplBa4 and labeled rDNA was similar to the pattern of the Ba1 (Figure 10a). The only distinct difference of the Ba2 was associated with its short arm that was painted with the WCPEplBa4. The FISH pattern of the Ba5 after FISH with WCPEplBa4 was similar to the FISH patterns of the $\mathrm{A}_{\mathrm{s}}$ (Figure 10d). FISH with the WCPEplBa4 on the $B_{s}$ from Turkish populations gave hybridization signal in distal part of the Btmini and in pericentric region of the Bt (Figure 10e,f). The FISH of WCPEplBa4 with the B24 from Spanish populations exhibited two interstitial hybridization signals in C-negative regions in $1 / 3 \mathrm{rd}$ and 2/3rd of the length and one in distal terminal region (Figure 10b).

\section{Discussion}

\subsection{Origin of Dot-Like $B_{s}$}

The $B_{\mathrm{s}}$ in grasshoppers vary in size from minute dot-like elements to a large chromosome equal to the largest autosome (Figures 1-10). We observed the dot-like $B_{\mathrm{s}}$ in N. tardus and N. cyanipes (Figure 1). The mechanism of chromosome rearrangement proving these dot-like $B_{s}$ remains unknown; however, these chromosomes resemble human small supernumerary marker chromosomes (SMCs). Many small SMCs are dot-like chromosomes and usually they exhibit mitotic and meiotic instability leading to mosaicism of small SMCs in tissues [33]. The $\mathrm{B}_{\mathrm{s}}$ of $N$. tardus also showed mosaicism. Two hypotheses were previously suggested for the mechanism of human small SMC origin: SMCs arise as a result of deletion of almost the whole arm(s) or by forming the inverted duplication of pericentromeric region of acrocentrics followed by inactivation of one of the centromeres [33]. In our study, the results of the FISH of WCPNtaB probe with metaphase chromosomes of $N$. tardus supports the hypothesis of their origination from a pericentromeric region of the acrocentrics. The DNA of the B chromosome showed homology to the pericentromeric regions of the L1 and S8 autosomes (Figure 1c) indicating them as the possible B chromosome ancestor. However, taking in account rapid evolution of repetitive DNA in the pericentromeric regions, we cannot regard these repeats as reliable phylogenetic markers.

The special features of $N$. tardus and $N$. cyanipes karyotype made us look for another hypothesis of the B chromosome origin in these species. In contrast to many grasshopper species, $N$. tardus and $N$. cyanipes have neo-XX/neo-XY sex chromosomes. They derived from the fusion of the ancestral $\mathrm{X}$ with one of autosomes. The small fragment containing centromere could arise as the by-product of the fusion. We suppose that this new small chromosome could evolve into modern $B_{s}$. The association of these $B_{s}$ with the terminal region of a short arm of neo-X chromosome (arm derived from the ancestral $\mathrm{X}$ ) in meiosis (Figure 1b) is an additional argument for this hypothesis.

\subsection{From Dot-Like $B_{s}$ to the Large Ones}

Traditional view on $\mathrm{B}$ chromosome evolution suggests that insertions into dot-like $\mathrm{B}_{\mathrm{s}}$ followed by DNA amplification lead to large $\mathrm{B}_{\mathrm{s}}[6]$. Data on the $\mathrm{B}_{\mathrm{s}}$ in Podisma species were involved earlier in the discussion of mechanisms of $B$ chromosome evolution [34]. The DNA amplification leads to enlargement of their C-positive regions significantly increasing the size of the $B_{s}$. The DNA amplified in the $B_{S}$ includes DNA fragments from ancestor chromosome and fragments inserted into $B_{S}$ on various stages of their evolution. $A_{s}$ a result, large $C$-positive $B_{s}$ contain different types of repeats, such as satDNA, mobile elements, and rDNA [34-36].

The high mobility of rDNA was shown for many species and in many grasshopper species the regions of $\mathrm{B}_{\mathrm{s}}$ appeared to be enriched with rDNA [5]. In E. plorans and P. sapporensis many C-positive regions of $B_{s}$ are enriched with rDNA [34,37]. Most part of rDNA in $B_{s}$ is non-functional [38]. Probably, the amplification of rDNA is frequently involved into formation of large C-positive regions of $A_{s}$ and $B_{s}$. These repeats can contribute to molecular composition of pericentric C-positive regions [28,39] and in formation of numerous additional C-positive arms of $\mathrm{A}_{\mathrm{s}}$, for instance, in P. sapporensis [31] and 
Eremopeza festiva [40]. However, the amplification of rDNA does not always occur in C-positive $\mathrm{B}_{\mathrm{s}}$ of grasshoppers. In other species involved in this study, the $\mathrm{B}_{\mathrm{s}}$ did not contain rDNA. It is possible that the amplification of rDNA takes place in the $B_{s}$ that initially contained these repeats or in species with highly mobile genetic elements containing DNA homologous rDNA.

SatDNA is another type of repetitive sequences mainly present in pericentomeric C-positive regions of $A_{s}$ in many species including grasshoppers [11,13,37,41]. In grasshoppers, containing no $B$ chromosome satDNA represents small portion of their genomes. In specimens of Pyrgomorpha conica without $B_{s}$ in their karyotypes, high-throughput analysis of satDNA revealed 87 satDNA variants, representing $9.4 \%$ of its genome [42]. In the main genome of Locusta migratoria, satDNA comprise only $2.4 \%$ of genomic DNA [42]. In contrast to the main genome, C-positive $B_{s}$ are enriched with satDNA. In studied B chromosome of Locusta migratoria, $65.2 \%$ of its DNA is consisted of this type of repeats [42]. Abundance of a certain type of satellite repeats can be altered by the DNA amplification. In the B chromosome of L. migratoria more than a half of DNA refer to one type of satellite repeat [42]. In E. plorans, $\mathrm{B}_{\mathrm{s}}$ are significantly enriched with $180 \mathrm{bp}$ satDNA repeat [43]. However, satellitome studies on grasshopper $B_{S}$ are in their beginning stage and additional intensive studies are required for understanding of the role of satDNA in B chromosome evolution.

The third type of repeats that can be involved in B chromosome development are mobile elements. It was thought that genetically inert $B_{\mathrm{s}}$ could serve as the targets for mobile element insertions and their accumulation [6]. However, earlier it was shown that mariner-like elements are located mostly in euchromatic regions of $A_{s}$ and $C$-negative regions of $B_{s}$. They were undetected in the regions enriched with rDNA and tandem repeats and in heterochromatic parts of the $B_{s}[35,36]$. Furthermore, study of the B chromosome in L. migratoria showed that transposable elements (TE) comprise only $18 \%$ of its content. It is significantly lower than TE content in $\mathrm{A}_{\mathrm{s}}$ [42]. Probably, the role of TE in growth of $\mathrm{C}$-positive regions of $\mathrm{B}$ chromosomes is nonessential.

Besides the insertion of rDNA, satDNA, and mobile elements, other repeats could also contribute to the $\mathrm{B}$ chromosome development. We had expected that in some $\mathrm{B}_{\mathrm{S}}$, amplification of telomeric repeats could also take place like in development of large C-positive regions of chromosomes in stick insects [44]. However, to date large C-positive regions of $B_{s}$ enriched with telomeric repeats have not been observed. The only exception was a region in the B chromosome of B. gebleri (Figure 5). Small unique DNA fragments of the main genome could probably also be inserted into the $B_{s}$ without forming $C$-negative region. This phenomenon was described in studies of some $B_{s}$ in mammals [19-21].

The factors determining the frequency of the dot-like B chromosome arising and their further evolution are associated with the basic genome particularities: location of hotspots of chromosome rearrangements close to centromere; high mobility of some genetic elements; predisposition to DNA amplification. All these genome characteristics and processes might play a similar role in different species. For instance, hotspots of chromosome rearrangements close to pericentromeric regions are associated with the small SMC arising in humans [33,45], the mobility of DNA fragments leads to formation of duplicon clusters [46-48], insertions of DNA fragments and their amplification could lead to the development of additional C-positive regions [49].

\subsection{The $B_{s}$ with $C$-Negative Regions}

Karyotyping of some grasshopper species revealed mostly $C$-negative $B_{s}$ and $B_{s}$ with $C$-negative regions. These $B_{s}$ can be divided into at least three groups according to their morphology and hypothetical evolutionary stage: (i) mostly $\mathrm{C}$-negative $\mathrm{B}_{\mathrm{s}}$ (Figures 2-4); (ii) the $\mathrm{B}_{\mathrm{s}}$ containing large C-positive and C-negative region(s) (Figures 5-10); (iii) mostly C-positive $B_{\mathrm{s}}$ and $\mathrm{C}$-positive $\mathrm{B}_{\mathrm{s}}$ with small C-negative region(s) (Figures 7-10). We consider the transposition of large $C$-negative regions from $A_{s}$ into the $B_{s}$ on an advanced stage of their evolution being at least rare events and for explanation of the existence of $B_{s}$ with large $C$-negative region(s) we looked for different mechanisms of such B chromosome development. 
Cell functioning is regulated by complex interactions of multiple genes and gene dosage balance is crucial in this process. Usually aneuploidy has detrimental effects on the ontogenesis [50]. The example of a high frequency of aneuploidy of the large chromosome in free-living flatworm Macrostomum lignano turned out to be hidden polyploidy [51-53]. At least partial inactivation of the $B_{S}$ containing $C$-negative regions is required to avoid genetic imbalance [9] otherwise they should be prone to negative selection. In mostly heterochromatic $\mathrm{B}_{\mathrm{s}}$, genes in their small $\mathrm{C}$-negative regions are probably inactivated due to their close proximity to heterochromatic blocks. Human small SMCs with small euchromatic regions also show no visible effect on phenotype of their carriers [54]. This suggests that such $B_{s}$ can appear to be neutral or almost neutral elements for natural selection. But for the mostly $C$-negative $B_{s}$ the problem of dosage balance should still exist. Earlier, the $\mathrm{X}$ and small autosomes were considered the most probable sources for $B_{s}$. The extra $X$ chromosome could be tolerated due to dosage compensation mechanisms while small autosomes could be tolerated due to the low number of genes [6,9]. However, we should take into account that in some grasshoppers a high level of polysomy of some autosomes was observed and these polysomic elements do not cause problems in meiosis exhibiting signs of heteropicnocity and chromosome inactivation [55]. This suggests that even extra copies of autosomes in grasshoppers can escape from negative selection. These data inspired us to come back to consideration of large and medium autosomes as ancestors of $B_{S}$ in more detail.

We revealed and described $B_{s}$ in Aeropus sibiricus that are probably on their early evolutionary stage. The morphology and C-banding patterns of these $B_{s}$ were very similar to the chromosomes of the basic set (Figure 2). Similar $B_{\mathrm{S}}$ were observed in other population of $A$. sibiricus and even initially misinterpreted as aneuploidy [56]; however, later they were referred to as $B_{S}[57,58]$. In meiosis, they formed multivalents with each other and did not interfere with bivalents of $A_{s}$. Other early evolutionary stages of $\mathrm{B}_{\mathrm{S}}$ were observed in Chorthipps jacobsoni and Chorthippus apricarius (Figures 3 and 4 ), however, these $B_{s}$ are probably on a more advanced stage of their evolution. In $C$. jacobsoni, the $B_{s}$ underwent rearrangements resulted in iso- $B_{s}$. More complex reorganization (such as inversions, new $C$-positive region development, and other rearrangements) has occurred in evolution of the $B_{s}$ in $C$. apricarius. Occurrence of the whole $C$-negative $B_{s}$ are rare; however, $\mathrm{C}$-negative morphotypes of $\mathrm{B}_{\mathrm{s}}$ were also described in Greek, Turkish and Armenian populations of E. plorans [16,32] and in Abracris flavolineatus [59].

The $B_{S}$ containing large $C$-positive and $C$-negative regions are probably on a more evolutionary advanced stage. The $B_{s}$ of this type are more frequent. They were revealed among of $B_{s}$ in E. plorans [32,60-62] (Figure 9), P. sapporensis [30] (Figure 7), Bryodema geblery (Figure 5), Myrmeleotettix maculatus [63], Xyleus discoideus angulatus [22], and in L. migratoria [64] showing various morphotypes. Often these chromosomes contain a large C-positive region and smaller alternating C-positive and C-negative regions. The morphology of these chromosomes can be acrocentric or metacentric (i.e., isochromosomes) (Figures 7 and 9).

Finally, the massive part of the advanced $B_{s}$ are mostly $C$-positive $B_{s}$ or $C$-positive $B_{s}$ with small $\mathrm{C}$-negative region(s). Many described $\mathrm{B}_{\mathrm{s}}$ of this type look like completely or almost completely heterochromatic. This stage of $B$ chromosome evolution is indistinguishable from large $B_{s}$ evolved from dot-like $B_{s}$ after amplification of their DNA. However, some of these entirely C-positive $B_{s}$ could contain small euchromatic regions visible only in very stretched chromosomes. For example, the C-positive Ba1 in E. plorans contained small regions painted with euchromatic DNA probe (Figure 10a,d). The sequencing of microdissected libraries of mammalian $\mathrm{B}_{\mathrm{s}}$ revealed DNA fragments homologous to a unique DNA located in different chromosomes of the basic set [19-21]. The question "are the C-negative regions of the $B_{s}$ the remnants of large euchromatic regions earlier present in the $B$ or are they the result of multiple insertions/duplications of a small euchromatic chromosome region?" remains open. Probably both types of $B_{s}$ are present in natural populations. Furthermore, in some $B_{s}$ small insertions of DNA fragments from euchromatic regions of $A_{s}$ seem to be too small to form visible $C$-negative regions in these $B_{s}[19,20]$. 


\subsection{DNA Content of C-Negative Regions in $B_{S}$}

Grasshopper genomes are the largest genomes among insects and are significantly enriched with repeats [65-68]. These repeats are differentially distributed among C-positive and C-negative regions. For instance, C-negative regions contain more mobile elements than C-positive ones [35,36]. This allowed generating a microdissected DNA probe from C-negative regions that paints only C-negative chromatin [31] even in different closely related species [29,34,69]. However, in $B_{S} C$-negative regions can be enriched with repeats that differ from dispersed repeats of $C$-negative regions of $A_{s}$. The C-negative B7 in P. sapporensis is a perfect example of such $B_{\mathrm{S}}$ [31]. FISH with DNA probe generated from a C-negative region of $\mathrm{A}$ chromosome gave signal only in a distal region of the B7. The rest of its $\mathrm{C}$-negative regions remained unpainted. DNA content of the proximal part of the $\mathrm{B} 7$ remains unknown. If it was formed with DNA amplification of C-negative region of the A chromosome, it should have usual interspersed repeats and should be painted with a DNA probe derived from the euchromatic region of A chromosome [70]. The loss of all interspersed repeats from these regions is unlikely. In addition, we cannot accept the B chromosome origin from interspecific hybridization of closely related species. Interspersed repeats of euchromatic regions in Podisma species show high homology [34]. $A_{s}$ concerns the C-negative $B_{S}$ in the Greek population of E. plorans, they showed enrichment for rDNA and $180 \mathrm{bp}$ satDNA [16]. Maybe these $\mathrm{B}_{\mathrm{s}}$ are on the early stages of repeat expansion and they are not able to convert C-negative regions to C-positive ones. In E. plorans, we revealed the mostly $\mathrm{C}$-negative autosome containing numerous dispersed clusters of repeats homologous to DNA of the Ba4 (Figure 10c), which supports this hypothesis. These intercalary repeat clusters are too small to form visible C-positive blocks and their distribution was limited with the only autosome, S10.

The $C$-negative regions of different sizes in the $B_{s}$ pose additional questions about the DNA content of $B_{\mathrm{s}}$ and transcriptional activity of these genes. There is only a little information about their transcriptional activity. Recently, ten genes were discovered in the $\mathrm{B}_{\mathrm{s}}$ of E. plorans. The CIP2A, GTPB6, KIF20A, and MTG1 were complete while the CKAP2, CAP-G, HYI, MYCB2, SLIT, and TOP2A were truncated. At least a half of these genes are transcriptionally active [71]. It should be noted that these genes are involved in cell division processes as well as the genes of $B_{s}$ of vertebrates [19-21,72-74]. However, the exact location and flanking regions of these genes are mostly unknown. Their location in C-positive regions could not be excluded. We should note that DNA transcription in heterochromatic regions was shown in many species on different stages of individual development and in some other special situations $[75,76]$. The role and significance of transcription taking place in the $B_{s}$ should be thoroughly studied in the future.

\subsection{Mechanisms of C-Negative B Chromosome Evolution}

Two forces driving B chromosome evolution can be generally described as the DNA amplification from one side and the degradation of some chromosome regions from another side. We suppose that in further development of $C$-negative $B_{s}$, their degradation will be probably the main process, while in dot-like $B_{s}$ we should expect the amplification of their DNA. The mechanisms of degradation may include generation and distribution of repeat clusters along the euchromatic arm of the precursor chromosome like the distribution of repeat clusters along the euchromatic arm of the S10 in E. plorans (Figure 10c). The expansion of the repeats cluster along the chromosome probably occurred through inversions, transferring the part of cluster along the chromosome arm. After transposition, amplification of its DNA resulted in growing the repeat cluster in size. We suggest at least two consequences of this process. Due to inversions, crossing over between original and rearranged autosomes should be suppressed and the frequency of meiotic abnormalities involving them should be increased leading to a higher frequency of aneuploidy on this chromosome. Additionally, transcription activity of genes located between heterochromatic blocks could be decreased, saving the specimens with trisomy from negative natural selection. Subsequent deletions of $C$-negative regions located between repeat clusters could decrease genetic imbalance on this part of the genome and lead to the 
B chromosome arising. Smaller size of the Ba4 can be explained by the advanced stages of elimination of the euchromatic regions located between these repeat clusters. The elimination of euchromatic regions may eventually lead to a fusion of repeat clusters into a continuous region composed of repetitive DNA, showing pattern of $\mathrm{C}$-positive staining. Among the studied $\mathrm{B}_{\mathrm{s}}$ there are chromosomes containing proximal or distal enlarged C-positive regions. Probably, the distribution of repeat clusters along the chromosome arm followed by the elimination of euchromatic regions can start from the proximal or distal part of the chromosome, leading to the formation of a visible C-positive block in a corresponded chromosome region. A strong support of this hypothesis was provided by finding of the neo-Y degradation in Pamphagidae grasshoppers leading morphotypes of the neo-Ys that are similar to morphotypes of some studied $B_{\mathrm{S}}$ [27-29].

\subsection{Lesson from neo-Y Chromosomes in Pamphagidae Grasshoppers}

Degradation of euchromatic part of ancestor chromosome played a crucial role in neo-Y chromosome evolution in Pamphagidae grasshoppers. In contrast to standard $X X_{+} / \mathrm{X}_{0}{ }^{\wedge}$ sex determination chromosome system the neo-sex chromosomes are rare for grasshoppers. However, the frequency of the fusion of the autosome with the $X$ chromosome in Pamphagidae grasshoppers appeared to be unusually high. The neo-Y chromosome in these grasshoppers undergoes a process of intensive degradation $[27,29,40,77-79]$. Different stages of the neo-Y evolution can be observed in species of this family. In early stages, the neo-Ys are fully homologous to the arm of the neo-X derived from the autosome. In the next stage of its development, the neo-Ys are characterized with small interstitial C-positive regions accumulated in its proximal part. More advanced neo-Ys appear to be smaller due to the deletion of C-negative regions located between C-positive blocks. The fusion of the small interstitial C-blocks forms the large ones [27,29]. Dissemination of repeats followed by the development of repeat clusters and the deletion of the euchromatic regions located between them on further stages may be a universal mechanism of the chromosome degradation in grasshoppers that could be also involved in process of the B chromosome development.

\subsection{Many Ways to the $B_{S}$}

We cannot discard any hypothetical mechanisms suggested earlier $[5,6,10,13,71,80]$ and mentioned above. On the contrary, we suppose that many of them or even a combination of them can be involved in the appearance and further evolution of the $B_{s}$. Involvement of different mechanisms depends on particularities of the basic genome. Their diversity results in the great variety of the $B_{s}$ that differ in their morphology, size, and DNA content. Nevertheless, being different in the initial stage, they can probably converge on a certain stage of their evolution acquiring similar morphology. However, then $B_{s}$ could pass through further rearrangements to the next stage of evolution. Besides insertions and DNA amplification, $B_{s}$ are also prone to converting to biarmed chromosomes. Probably the break near centromeric region and incorrect DNA reparation can result in iso- $\mathrm{B}_{\mathrm{s}}$. Then each arm undergoes independent evolution. A similar mechanism of iso-B chromosome development was suggested for the B chromosome evolution in the Korean field mouse, Apodemus peninsula [81].

\subsection{The Maintenance of $B_{s}$ in Natural Populations}

The existence of positive or negative natural selection against the specimens with $B_{s}$ remains an open question. A strong positive selection in favor of the $B_{s}$ should increase the frequency of specimens with the $B_{S}$ in populations and probably increase their number per specimens. Strong negative selection should lead to the loss of the $B_{s}$. There are species without the $B_{s}$ and the $B_{s}$ are present in the majority of specimens [82]. However, in many species the specimens with $B_{s}$ represent a minor part in most of populations. From our point of view, such maintenance of the $B_{s}$ requires at least two factors. For example, we can suggest weak negative natural selection against the $\mathrm{B}_{\mathrm{s}}$ on one hand, and on the other, the preferential $\mathrm{B}$ chromosome transfer in oocyte or more efficient spermatocytes with the $B_{s}$. This drive will increase the probability of the $B$ chromosome transfer to the next generation. We should also consider an alternative suggestion: positive natural selection for 
carriers of the $\mathrm{B}_{\mathrm{S}}$ and decreased frequency of the B chromosome transfer to the next generation. Data on the genes present in the $B_{S}$ of E. plorans and their transcriptional activity [71] stimulate intensive study, keeping in mind both suggestions. It is also possible that among different kinds of $B_{s}$ (the $B_{s}$ differ by their origin, DNA composition, influence on adaptiveness of their carriers, and being at different stages of their evolution) there are different modes of selection. For instance, the loss of euchromatic regions in $B_{s}$ neutralize the mode of selection, but enlargement of their $C$-positive regions will cause negative selection. The development of $B_{s}$ can lead to switching of the natural selection direction and converting the maintenance of the $B_{s}$ in populations to a dynamic process providing the permanent wide diversity of the $B_{s}$ that depends on particularities of basic genome and habitat versatility.

\section{Conclusion}

The possible mechanisms of the appearance and evolution of the Bs in grasshoppers were analyzed and discussed. We suggest that different mechanisms can be involved in these processes. One of them includes the stage of a small supernumerary chromosome with the following stages of DNA fragment incorporation and amplification. Another mechanism could be associated with the distribution of repeat clusters along the arm of the A chromosome and the loss of euchromatic regions located between them. Both autosomes and sex chromosomes can be involved in the B chromosome's appearance. It is probable that at least in some cases the process of the B chromosome evolution is similar to the neo- $Y$ degradation described in Pamphagidae grasshoppers. The origination and evolution of the Bs depends on such particularities of the basic genome as a location of hotspots of chromosome rearrangements, mobility of various genomic elements, and a predisposition of some DNA fragments to their amplification. In some grasshoppers, rDNA or DNA fragments homologous to rDNA are prone to transpositions and amplification, leading in some species to enrichment of the B chromosome regions for DNA at least partly homologous to rDNA. The question of natural selection in favor or against the Bs is still open. Furthermore, we cannot rule out the switchover to different direction of natural selection during B chromosome evolution.

Further studies on the grasshopper Bs shall be devoted to identification of their euchromatic regions, and determination of their gene content and transcription activity, including its role and significance. The question that requires special attention concerns the determination of DNA content of mysterious C-negative B chromosome regions containing no or few repeats that are typical for euchromatic regions of As.

Author Contributions: Conceptualization, I.Y.J., A.G.B. and N.B.R.; Data curation, A.G.B.; Formal analysis, I.Y.J. and V.V.D.; Funding acquisition, A.G.B.; Investigation, I.Y.J., A.G.B., V.V.D. and N.B.R.; Methodology, A.G.B. and N.B.R.; Resources, A.G.B. and N.B.R.; Supervision, A.G.B. and N.B.R.; Visualization, I.Y.J.; Writing-original draft, I.Y.J. and N.B.R.; Writing-review and editing, I.Y.J., A.G.B. and N.B.R.

Funding: This research was funded by the project \#0324-2018-0019 of The Federal Research Center Institute of Cytology and Genetics, the Siberian Branch of Russian Academy of Science and research by the Russian Foundation for Basic Research (grant \#18-04-00192) and the Federal Fundamental Scientific Research Program for 2013-2020, grant N VI.51.1.5 (AAAA-A16-116121410121-7).

Acknowledgments: We thanks Juan Pedro Martinez Camacho for donating material of E. plorans with the B24 chromosome; Olesya Buleu, for technical assistance in chromosome preparation and C-banding, Tatiana Karamysheva for assistance with E. plorans microdissected DNA library preparation; Kira Zadesenets for assistance with P. sapporensis microdissected DNA library preparation. The authors express gratitude to Haruki Tatsuta (Ryukyu University, Nishihara, Japan) and Elżbieta Warchałowska-Śliwa for their comprehensive assistance in Hokkaido, and Nadezhda Vorobyeva for English language proofpreading.

Conflicts of Interest: The authors declare no conflict of interest. The funders had no role in the design of the study; in the collection, analyses, or interpretation of data; in the writing of the manuscript, or in the decision to publish the results.

\section{References}

1. Wilson, B.E. The supernumerary chromosomes of Hemiptera. Sci. N. Y. 1907, 26, 870-871.

2. Jones, N. New species with B chromosomes discovered since 1980. Nucleus 2017, 60, 263-281. [CrossRef]

3. D'Ambrosio, U.; Alonso-Lifante, M.P.; Barros, K.; Kovařik, A.; Mas de Xaxars, G.; Garcia, S. B-chrom: A database on B-chromosomes of plants, animals and fungi. New Phytol. 2017, 635-642. [CrossRef] [PubMed] 
4. Palestis, B.G.; Cabrero, J.; Trivers, R.; Camacho, J.P.M. Prevalence of B chromosomes in Orthoptera is associated with shape and number of A chromosomes. Genetica 2010, 138, 1181-1189. [CrossRef] [PubMed]

5. Camacho, J.P.M.; Sharbel, T.F.; Beukeboom, L.W. B-chromosome evolution. Philos. Trans. R. Soc. B Biol. Sci. 2000, 355, 163-178. [CrossRef] [PubMed]

6. Camacho, J.P.M. Chapter 4-B Chromosomes. In The Evolution of the Genome; Gregory, T., Ed.; Academic Press: Burlington, NJ, USA, 2005; pp. 223-286. ISBN 978-0-12-301463-4.

7. Blagojević, J.; Vujošević, M. B chromosomes and developmental homeostasis in the yellow-necked mouse, Apodemus flavicollis (Rodentia, Mammalia): Effects on nonmetric traits. Heredity 2004. [CrossRef] [PubMed]

8. Jojić, V.; Blagojević, J.; Vujošević, M. B chromosomes and cranial variability in yellow-necked field mice (Apodemus flavicollis). J. Mammal. 2011. [CrossRef]

9. Hewitt, G.M. The integration of supernumerary chromosomes into the orthopteran genome. Cold Spring Harb. Symp. Quant. Biol. 1974, 38, 183-194. [CrossRef] [PubMed]

10. Camacho, J.P.M.; Schmid, M.; Cabrero, J. B chromosomes and sex in animals. Sex. Dev. 2011, 5, $155-166$. [CrossRef] [PubMed]

11. Ruiz-Ruano, F.J.; López-León, M.D.; Cabrero, J.; Camacho, J.P.M. High-throughput analysis of the satellitome illuminates satellite DNA evolution. Nat. Publ. Gr. 2016, 6, 128333. [CrossRef] [PubMed]

12. Palacios-Gimenez, O.M.; Dias, G.B.; de Lima, L.G.; Kuhn, G.C.E.S.S.; Ramos, É; Martins, C.; Cabral-de-Mello, D.C. High-throughput analysis of the satellitome revealed enormous diversity of satellite DNAs in the neo-Y chromosome of the cricket Eneoptera surinamensis. Sci. Rep. 2017, 7, 6422. [CrossRef] [PubMed]

13. Ruiz-Ruano, F.J.; Castillo-Martínez, J.; Cabrero, J.; Gómez, R.; Camacho, J.P.M.; López-León, M.D. High-throughput analysis of satellite DNA in the grasshopper Pyrgomorpha conica reveals abundance of homologous and heterologous higher-order repeats. Chromosoma 2018, 127, 323-340. [CrossRef] [PubMed]

14. Cabrero, J.; Camacho, J.P.M. Cytogenetic studies in gomphocerine grasshoppers. I. Comparative analysis of chromosome C-banding pattern. Heredity 1986, 56, 365-372. [CrossRef]

15. Santos, J.L.; Arana, P.; Giráldez, R.; Girfildez, R.; Giráldez, R.; Girfildez, R. Chromosome C-banding patterns in Spanish Acridoidea. Genetica 1983, 61, 65-74. [CrossRef]

16. Abdelaziz, M.; Teruel, M.; Chobanov, D.; Camacho, J.P.M.; Cabrero, J. Physical mapping of rDNA and satDNA in A and B chromosomes of the grasshopper Eyprepocnemis plorans from a Greek population. Cytogenet. Genome Res. 2007, 119, 143-146. [CrossRef] [PubMed]

17. López-León, M.D.; Neves, N.; Schwarzacher, T.; Heslop-Harrison, J.S.; Hewitt, G.M.; Camacho, J.P.M. Possible origin of a B chromosome deduced from its DNA composition using double FISH technique. Chromosom. Res. 1994, 2, 87-92. [CrossRef]

18. Teruel, M.; Ruíz-Ruano, F.J.; Marchal, J.A.; Sánchez, A.; Cabrero, J.; Camacho, J.P.M.; Perfectti, F. Disparate molecular evolution of two types of repetitive DNAs in the genome of the grasshopper Eyprepocnemis plorans. Heredity 2014, 112, 531-542. [CrossRef] [PubMed]

19. Makunin, A.I.; Kichigin, I.G.; Larkin, D.M.; O’Brien, P.C.M.; Ferguson-Smith, M.A.; Yang, F.; Proskuryakova, A.A.; Vorobieva, N.V.; Chernyaeva, E.N.; O’Brien, S.J.; et al. Contrasting origin of B chromosomes in two cervids (Siberian roe deer and grey brocket deer) unravelled by chromosome- specific DNA sequencing. BMC Genom. 2016, 17. [CrossRef] [PubMed]

20. Makunin, A.I.; Rajičić, M.; Karamysheva, T.V.; Romanenko, S.A.; Druzhkova, A.S.; Blagojević, J.; Vujošević, M.; Rubtsov, N.B.; Graphodatsky, A.S.; Trifonov, V.A. Low-pass single-chromosome sequencing of human small supernumerary marker chromosomes (sSMCs) and Apodemus B chromosomes. Chromosoma 2018, 127, 301-311. [CrossRef] [PubMed]

21. Makunin, A.; Romanenko, S.; Beklemisheva, V.; Perelman, P.; Druzhkova, A.; Petrova, K.; Prokopov, D.; Chernyaeva, E.; Johnson, J.; Kukekova, A.; et al. Sequencing of Supernumerary Chromosomes of Red Fox and Raccoon Dog Confirms a Non-Random Gene Acquisition by B Chromosomes. Genes 2018, 9, 405. [CrossRef] [PubMed]

22. Loreto, V.; Cabrero, J.; López-León, M.D.; Camacho, J.P.M.; Souza, M.J. Possible autosomal origin of macro B chromosomes in two grasshopper species. Chromosome Res. 2008, 16, 233-241. [CrossRef] [PubMed]

23. Darlington, C.D.; la Cour, L.F. The Handling of Chromosomes, 5th ed.; George Allen And Unwin Ltd.: London, UK, 1969; ISBN 0045750130. 
24. Bugrov, A.G.; Karamysheva, T.V.; Rubtsov, D.N.; Andreenkova, O.V. Comparative FISH analysis of distribution of $\mathrm{B}$ chromosome repetitive DNA in A and B chromosomes in two subspecies of Podisma sapporensis (Orthoptera, Acrididae). Cytogenet. Genome Res. 2004, 106, 284-288. [CrossRef] [PubMed]

25. Telenius, H.; Carter, N.; Bebb, C.E.; Nordensjold, M.; Ponder, B.A.; Tunnacliffe, A. Degenerate oligonucleotideprimed PCR: General amplification of targeted DNA by single degenerate primer. Genomics 1992, 13, 718-725. [CrossRef]

26. Rubtsov, N.B.; Karamisheva, T.V.; Astakhova, N.M.; Liehr, T.; Claussen, U.; Zhdanova, N.S. Zoo-FISH with region-specific paints for mink chromosome $5 \mathrm{q}$ : Delineation of inter-and intrachromosomal rearrangements in human, pig, and fox. Cytogenet. Genome Res. 2000, 90, 268-270. [CrossRef] [PubMed]

27. Jetybayev, I.Y.; Bugrov, A.G.; Ünal, M.; Buleu, O.G.; Rubtsov, N.B. Molecular cytogenetic analysis reveals the existence of two independent neo-XY sex chromosome systems in Anatolian Pamphagidae grasshoppers. BMC Evol. Biol. 2017, 17, 20. [CrossRef] [PubMed]

28. Jetybayev, I.E.; Bugrov, A.G.; Karamysheva, T.V.; Camacho, J.P.M.; Rubtsov, N.B. Chromosomal localization of ribosomal and telomeric DNA provides new insights on the evolution of Gomphocerinae grasshoppers. Cytogenet. Genome Res. 2012, 138, 36-45. [CrossRef] [PubMed]

29. Jetybayev, I.Y.; Bugrov, A.G.; Buleu, O.G.; Bogomolov, A.G.; Rubtsov, N.B. Origin and evolution of the neo-sex chromosomes in Pamphagidae grasshoppers through chromosome fusion and following heteromorphization. Genes 2017, 8, 323. [CrossRef] [PubMed]

30. Warchałowska-Śliwa, E.; Bugrov, A.G.; Tatsuta, H.; Akimoto, S.I. B chromosomes, translocation between B and autosomes, and C-heterochromatin polymorphism of the grasshopper Podisma sapporensis Shir. (Orthoptera, Acrididae) in Hokkaido, northern Japan. Folia Biol. 2001, 49, 63-76.

31. Bugrov, A.G.; Karamysheva, T.V.; Pyatkova, M.S.; Rubtsov, D.N.; Andreenkova, O.V.; Elzbieta, W.-S.; Rubtsov, N.B. B chromosomes of the Podisma sapporensis Shir. (Orthoptera, Acrididae) analysed by chromosome microdissection and FISH. Folia Biol. 2003, 51, 1-12.

32. Dzyubenko, V.V.; Karagyan, G.A.; Çiplak, B.; Rubtsov, N.B.; Bugrov, A.G. The B chromosome polymorphism in Armenian and Turkey populations of the grasshopper Eyprepocnemis plorans plorans (Charpentier) (Orthoptera, Acrididae, Eyprepocnemidinae). Tsitologiya 2006, 48, 1016-1022.

33. Liehr, T.; Claussen, U.; Starke, H. Small supernumerary marker chromosomes (sSMC) in humans. Cytogenet. Genome Res. 2004, 107, 55-67. [CrossRef] [PubMed]

34. Bugrov, A.G.; Karamysheva, T.V.; Perepelov, E.A.; Elisaphenko, E.A.; Rubtsov, D.N.; Warchałowska-Śliwa, E.E.; Tatsuta, H.; Rubtsov, N.B. DNA content of the B chromosomes in grasshopper Podisma kanoi Storozh. (Orthoptera, Acrididae). Chromosom. Res. 2007, 15, 315-325. [CrossRef] [PubMed]

35. Montiel, E.E.; Cabrero, J. Gypsy, RTE and Mariner transposable elements populate Eyprepocnemis plorans genome. Genetica 2012, 140, 365-374. [CrossRef] [PubMed]

36. Palacios-Gimenez, O.M.; Bueno, D.; Cabral-de-Mello, D.C. Chromosomal mapping of two Mariner-like elements in the grasshopper Abracris flavolineata (Orthoptera: Acrididae) reveals enrichment in euchromatin. Eur. J. Entomol. 2014, 111, 329-334. [CrossRef]

37. López-León, M.D.; Cabrero, J.; Dzyubenko, V.V.; Bugrov, A.G.; Karamysheva, T.V.; Rubtsov, N.B.; Camacho, J.P.M. Differences in ribosomal DNA distribution on A and B chromosomes between eastern and western populations of the grasshopper Eyprepocnemis plorans plorans. Cytogenet. Genome Res. 2008, 121, 260-265. [CrossRef] [PubMed]

38. Ruiz-Estévez, M.; Badisco, L.; Broeck, J.V.; Perfectti, F.; López-León, M.D.; Cabrero, J.; Camacho, J.P.M. B chromosomes showing active ribosomal RNA genes contribute insignificant amounts of rRA in the grasshopper Eyprepocnemis plorans. Mol. Genet. Genom. 2014, 289, 1209-1216. [CrossRef] [PubMed]

39. López-León, M.D.; Cabrero, J.; Camacho, J.P.M. Unusually high amount of inactive ribosomal DNA in the grasshopper Stauroderus scalaris. Chromosom. Res. 1999, 7, 83-88. [CrossRef]

40. Bugrov, A.G.; Jetybayev, I.E.; Karagyan, G.H.; Rubtsov, N.B. Sex chromosome diversity in Armenian toad grasshoppers (Orthoptera, Acridoidea, Pamphagidae). Comp. Cytogenet. 2016, 10, 45-59. [CrossRef] [PubMed]

41. Plohl, M.; Meštrović, N.; Mravinac, B. Centromere identity from the DNA point of view. Chromosoma 2014, 123, 313-325. [CrossRef] [PubMed]

42. Ruiz-Ruano, F.J.; Cabrero, J.; López-León, M.D.; Sánchez, A.; Camacho, J.P.M. Quantitative sequence characterization for repetitive DNA content in the supernumerary chromosome of the migratory locust. Chromosoma 2018, 127, 45-57. [CrossRef] [PubMed] 
43. Cabrero, J.; López-León, M.D.; Bakkali, M.; Camacho, J.P.M. Common origin of B chromosome variants in the grasshopper Eyprepocnemis plorans. Heredity 1999, 83, 435-439. [CrossRef] [PubMed]

44. Liehr, T.; Buleu, O.; Karamysheva, T.; Bugrov, A.; Rubtsov, N. New Insights into Phasmatodea Chromosomes. Genes 2017, 8, 327. [CrossRef] [PubMed]

45. Liehr, T. Small Supernumerary Marker Chromosomes (sSMC); Springer: Berlin/Heidelberg, Germany, 2012; ISBN 978-3-642-20765-5.

46. Eichler, E.E. Masquerading Repeats: Paralogous Pitfalls of the Human Genome. Genome Res. 1998, 8, 758-762. [CrossRef] [PubMed]

47. Eichler, E.E.; Archidiacono, N.; Rocchi, M. CAGGG repeats and the pericentromeric duplication of the hominoid genome. Genome Res. 1999, 9, 1048-1058. [CrossRef] [PubMed]

48. Horvath, J.E.; Bailey, J.A.; Locke, D.P.; Eichler, E.E. Lessons from the human genome: Transitions between euchromatin and heterochromatin. Hum. Mol. Genet. 2001, 10, 2215-2223. [CrossRef] [PubMed]

49. Dorer, D.R.; Henikoff, S. Expansions of transgene repeats cause heterochromatin formation and gene silencing in Drosophila. Cell 1994, 77, 993-1002. [CrossRef]

50. Torres, E.M.; Williams, B.R.; Amon, A. Aneuploidy: cells losing their balance. Genetics 2008, 179, 737-746. [CrossRef] [PubMed]

51. Zadesenets, K.S.; Vizoso, D.B.; Schlatter, A.; Konopatskaia, I.D.; Berezikov, E.; Schärer, L.; Rubtsov, N.B. Evidence for karyotype polymorphism in the free-living flatworm, Macrostomum lignano, a model organism for evolutionary and developmental biology. PLoS ONE 2016, 11, e0164915. [CrossRef] [PubMed]

52. Zadesenets, K.S.; Schärer, L.; Rubtsov, N.B. New insights into the karyotype evolution of the free-living flatworm Macrostomum lignano (Platyhelminthes, Turbellaria). Sci. Rep. 2017, 7, 6066. [CrossRef] [PubMed]

53. Zadesenets, K.; Ershov, N.; Berezikov, E.; Rubtsov, N.; Zadesenets, K.S.; Ershov, N.I.; Berezikov, E.; Rubtsov, N.B. Chromosome Evolution in the Free-Living Flatworms: First Evidence of Intrachromosomal Rearrangements in Karyotype Evolution of Macrostomum lignano (Platyhelminthes, Macrostomida). Genes 2017, 8, 298. [CrossRef] [PubMed]

54. Hamid Al-Rikabi, A.B.; Pekova, S.; Fan, X.; Jancuskova, T.; Liehr, T. Small Supernumerary Marker Chromosome May Provide Information on Dosage-insensitive Pericentric Regions in Human. Curr. Genom. 2018, 19, 192-199. [CrossRef] [PubMed]

55. Hewitt, G.M.; John, B. Parallel Polymorphism for Supernumerary Segments in Chorthippus parallelus (ZETTERSTEDT) I. British Populations. Chromosoma 1968, 25, 319-342. [CrossRef] [PubMed]

56. Gosálvez, J.; López-Fernández, C. Extra heterochromatin in natural populations of Gomphocerus Sibiricus (Orthoptera: Acrididae). Genetica 1981, 56, 197-204. [CrossRef]

57. López-Fernández, C.; de la Vega García, C.; Gosálvez, J. Unstable B-Chromosomes in Gomphocerus Sibiricus (Orthoptera). Caryologia 1986, 39, 185-192. [CrossRef]

58. Gusachenko, A.M.; Vysotskaya, L.V.; Bugrov, A.G. Cytogeneic analysis of Siberian Grasshopper (Orthoptera, Acrididae) from Altay. Dokl. Biol. Sci. 1993, 328, 250-252.

59. Cella, D.M.; Ferreira, A. The Cytogenetics of Abracris flavolineata (Orthoptera, Caelifera, Ommatolampinae, Abracrini). Rev. Bras. Genet. 1991, 14, 315-329.

60. Henriques-Gil, N.; Santos, J.L.; Arana, P. Evolution of a complex B-chromosome polymorphism in the grasshopper Eyprepocnemis plorans. Chromosoma 1984, 89, 290-293. [CrossRef]

61. Bakkali, M.; Camacho, J.P.M. The B chromosome polymorphism of the grasshopper Eyprepocnemis plorans in North Africa: III. Mutation rate of B chromosomes. Heredity 2004, 92, 428-433. [CrossRef] [PubMed]

62. Camacho, J.P.M.; Carballo, A.R.; Cabrero, J. The B-chromosome system of the grasshopper Eyprepocnemis plorans subsp. plorans (Charpentier). Chromosoma 1980, 80, 163-176. [CrossRef]

63. Gallagher, A.; Hewitt, G.; Gibson, I. Differential Giemsa staining of heterochromatic B-chromosomes in Myrmeleotettix maculatus (Thunb.) (Orthoptera: Acrididae). Chromosoma 1972, 40, 167-172. [CrossRef]

64. Cabrero, J.; Viseras, E.; Camacho, J.P.M. The B-chromosomes of Locusta migratoria I. Detection of negative correlation between mean chiasma frequency and the rate of accumulation of the B's; a reanalysis of the available data about the transmission of these B-chromosomes. Genetica 1984, 64, 155-164. [CrossRef]

65. Bensasson, D.; Petrov, D.A.; Zhang, D.X.; Hartl, D.L.; Hewitt, G.M. Genomic gigantism: DNA loss is slow in mountain grasshoppers. Mol. Biol. Evol. 2001, 18, 246-253. [CrossRef] [PubMed]

66. Gregory, T.R. Animal Genome Size Database. Available online: http://www.genomesize.com (accessed on 18 October 2018). 
67. Li, X.-J.; Zhang, D.-C.; Wang, W.-Q.; Zheng, J.-Y. The chromosomal C-banding karyotypes of two pamphagid species from China. Chin. Bull. Entomol. 2008, 45, 549-553.

68. Camacho, J.P.M.; Ruiz-Ruano, F.J.; Martín-Blázquez, R.; López-León, M.D.; Cabrero, J.; Lorite, P.; Cabral-de-Mello, D.C.; Bakkali, M. A step to the gigantic genome of the desert locust: Chromosome sizes and repeated DNAs. Chromosoma 2015, 124, 263-275. [CrossRef] [PubMed]

69. Jetybayev, I.; Karamysheva, T.; Bugrov, A.; Rubtsov, N. Cross-hybridization of repetitive sequences from the pericentric heterochromatic region of Chorthippus apricarius (L.) with the chromosomes of grasshoppers from the Gomphocerini tribe. Eurasian Entomol. J. 2010, 9, 433-436.

70. Eckert, W.A.; Plass, C.; Weith, A.; Traut, W.; Winking, H. Transcripts from amplified sequences of an inherited homogeneously staining region in chromosome 1 of the house mouse (Mus musculus). Mol. Cell. Biol. 1991, 11, 2229-2235. [CrossRef] [PubMed]

71. Navarro-Domínguez, B.; Ruiz-Ruano, F.J.; Cabrero, J.; Corral, J.M.; López-León, M.D.; Sharbel, T.F.; Camacho, J.P.M. Protein-coding genes in B chromosomes of the grasshopper Eyprepocnemis plorans. Sci. Rep. 2017, 7, 45200. [CrossRef] [PubMed]

72. Yudkin, D.V.; Trifonov, V.A.; Kukekova, A.V.; Vorobieva, N.V.; Rubtsova, N.V.; Yang, F.; Acland, G.M.; Ferguson-Smith, M.A.; Graphodatsky, A.S. Mapping of KIT adjacent sequences on canid autosomes and B chromosomes. Cytogenet. Genome Res. 2007, 116, 100-103. [CrossRef] [PubMed]

73. Kichigin, I.G.; Lisachov, A.P.; Giovannotti, M.; Makunin, A.I.; Kabilov, M.R.; O’Brien, P.C.M.; Ferguson-Smith, M.A.; Graphodatsky, A.S.; Trifonov, V.A. First report on B chromosome content in a reptilian species: The case of Anolis carolinensis. Mol. Genet. Genom. 2018. [CrossRef] [PubMed]

74. Valente, G.T.; Conte, M.A.; Fantinatti, B.E.A.A.; Cabral-De-Mello, D.C.; Carvalho, R.F.; Vicari, M.R.; Kocher, T.D.; Martins, C. Origin and evolution of B chromosomes in the cichlid fish Astatotilapia latifasciata based on integrated genomic analyses. Mol. Biol. Evol. 2014, 31, 2061-2072. [CrossRef] [PubMed]

75. Hall, L.E.; Mitchell, S.E.; O'Neill, R.J. Pericentric and centromeric transcription: A perfect balance required. Chromosom. Res. 2012, 20, 535-546. [CrossRef] [PubMed]

76. Saksouk, N.; Simboeck, E.; Déjardin, J. Constitutive heterochromatin formation and transcription in mammals. Epigenet. Chromatin 2015, 8, 3. [CrossRef] [PubMed]

77. Bugrov, A.G.; Grozeva, S. Neo-XY chromosome sex determination in four species of the pamphagid grasshoppers (Orthoptera, Acridoidea, Pamphagidae) from Bulgaria. Caryologia 1998, 51, 115-121. [CrossRef]

78. Bugrov, A.G.; Warchałowska-Śliwa, E. Chromosome numbers and C-banding patterns in some Pamphagidae grasshoppers (Orthoptera, Acridoidea) from the Caucasus, Central Asia, and Transbaikalia. Folia Biol. 1997, 45, 133-138.

79. Bugrov, A.G.; Buleu, O.G.; Jetybayev, I.E. Chromosome polymorphism in populations of Asiotmethis heptapotamicus (Zub.) (Pamphagidae, Thrinchinae) from Kazakhstan. Eurasian Entomol. J. 2016, 15, 545-549.

80. Teruel, M.; Cabrero, J.; Perfectti, F.; Camacho, J.P.M. B chromosome ancestry revealed by histone genes in the migratory locust. Chromosoma 2010, 119, 217-225. [CrossRef] [PubMed]

81. Rubtzov, N.B.; Borissov, Y.M.; Karamysheva, T.V.; Bochkarev, M.N.; Rubtsov, N.B.; Borosov, Y.M.; Karamysheva, T.V.; Bochkarev, M.N.N. The mechanisms of formation and evolution of B chromosomes in Korean field mice Apodemus peninsulae (Mammalia, Rodentia). Russ. J. Genet. 2009, 45, 389-396. [CrossRef]

82. Rubtsov, N.B.; Kartavtseva, I.V.; Roslik, G.V.; Karamysheva, T.V.; Pavlenko, M.V.; Iwasa, M.A.; Koh, H.S. Features of the B chromosome in Korean field mouse Apodemus peninsulae (Thomas, 1906) from Transbaikalia and the Far East identified by the FISH method. Russ. J. Genet. 2015, 51, 278-288. [CrossRef]

(C) 2018 by the authors. Licensee MDPI, Basel, Switzerland. This article is an open access article distributed under the terms and conditions of the Creative Commons Attribution (CC BY) license (http://creativecommons.org/licenses/by/4.0/). 